\title{
The Role of Universities in the Protection of Refugees and Other Migrants
}

\author{
A View from Brazil and Latin America
}

\author{
Liliana L. Jubilut
}

ABSTRACT: This article reflects on the roles that universities from Brazil and Latin America can play in the protection of refugees and other migrants in the context of a debate of "recentering" the Global South in Refugee and Forced Migration Studies. To that end, it draws on teaching, research, and outreach initiatives as well as general reflections on the topic, and presents examples from Brazil and Latin America.

KEYWORDS: academic, Brazil, Global Compact, Latin America, outreach, refugees, research, teaching, universities

\section{Introduction}

A whole-of-society approach to migration and the protection of refugees and other migrantsthat is, an approach in which not only governments and states take part in initiatives and policies, but rather all societal sectors are in engaged in their protection-has been championed recently, for example, by the Global Compact on Safe, Orderly and Regular Migration ${ }^{1}$ (as noted in its guiding principles, paragraph 15). Within this framework, universities can play a significant role and be leading actors in different ways: for instance, universities can produce knowledge, and have a wide influence, being able to impact (directly) their students through teaching and related activities, as well as the communities in which they are situated and other relevant actors-such as decision makers-locally, regionally, and/or globally.

This article presents some of these possibilities both in general and in terms of Brazil and Latin America, drawing on a number of past and ongoing academic efforts ${ }^{2}$ to explore the different opportunities and challenges for universities to actively play such roles to support the needs and rights of refugees and other migrants. It derives from an invitation by the editors of Migration and Society to reflect, in the context of a debate on how to recenter the Global South in studies of migration, on how universities in Brazil and Latin America can be engaged in refugees' and other migrants' protection as well as to identify some examples of good practices by universities in said scenarios. It is built as an opinion piece, therefore with little referencing and a relatively fluid construction of arguments. It begins with current practices and challenges and then highlights aspects that need to be taken into consideration in future endeavors. 


\section{The Production and Circulation of Academic Knowledge in Brazil and Latin America}

Universities are ideally situated to produce knowledge, including in the field of Refugee and Migration Studies, and to share this knowledge both with students and with diverse stakeholders on local, national, and international levels. Indeed, universities can contribute both in creating new knowledge and in advancing theoretical and empirical understandings, thus assisting in explaining migration contexts and scenarios to diverse audiences.

The UNHCR Sergio Vieira de Mello Chair is an example of an important initiative developed to promote such a role in Brazil. In 2003, following the August terrorist attack in Baghdad, the United Nations High Commissioner for Refugees (UNHCR) decided to honor Sergio Vieira de Mello-who had spent most of his United Nations (UN) career at UNHCR and who died in the attack while performing his role as the UN Secretary General Special Representative in Iraq-by establishing partnerships with Brazilian universities. The partnerships are implemented through the institution of university chairs titled UNHCR Sergio Vieira de Mello Chair (of which there are currently 22 in Brazil ${ }^{3}$ ), and which commit to develop actions in teaching, research, and outreach. It is to these three areas that this article now turns.

\section{Teaching and Access}

The teaching component has a dual focus: on the one hand, teaching the pertinent fields of Science per se (such as International Refugee Law and Theories and Practices of Migration) and its correlated and complementary fields (such as Human Rights, Humanitarian Law, Humanitarian Assistance, Human Geography, and Development) and on the other, allowing refugees and other migrants to have access to university education.

In terms of teaching about refugees and other migrants, the practice in the region seems to be a combination of theory and case studies, as well as syllabi with mixed bibliographies to encompass works in English and Portuguese and/or Spanish. In Brazil, a growing interest in refugee issues has been perceived, and it was followed by an increase in the teaching of courses on refugees and other migrants. It seems that most courses focus strongly on a specific area but also adopt an interdisciplinary perspective, at least for the basic theoretical concepts.

An initiative to be mentioned in the teaching framework in Brazil is the "International Refugee Law Course for University Professors," which in 2019 held its fourth edition. ${ }^{4}$ Inspired by a similar concept adopted by the International Committee of the Red Cross in Brazil, the free-ofcharge course was created in $2007^{5}$ and aims to train and/or update the knowledge of university professors in International Refugee Law, so that they can be catalysts, multiplying the sharing of knowledge in the area. In spite of its title, the course is also open to Masters students and $\mathrm{PhD}$ candidates, as well as those working directly in refugee protection (through the government, civil society, or international organizations). In all of its editions the course was brought about by partnerships with universities, thus having an academic institutional nature. It has counted on the support of UNHCR in all its editions, and has seen a fourfold increase in its participants, with over 80 in its most recent iteration.

With regard to strengthening refugees' and other migrants' access to universities as students, a range of strategies can be adopted, including the development of specific entry processes, the introduction of entry quotas, a commitment to supporting performance upon admission, follow-ups with strategies in place to address any difficulties based on the students' specific background, in addition to the provision of scholarships. 
In Brazil, most initiatives aiming to enhance access to universities have focused on supporting recognized refugees, although a number of universities have expanded the scope of their actions to encompass asylum seekers, ${ }^{6}$ humanitarian visa holders, ${ }^{7}$ or vulnerable migrants. ${ }^{8}$ Most efforts in this area focus on enhancing routes for refugees to access universities, either through tailored admissions processes or entry quotas - in the former, refugees sit specific tests, and in the latter they sit general tests; in both, however, they compete for places only against other refugees. As of October 2019, 22 Brazilian universities have special access programs for refugees, ${ }^{9}$ which could entail having places that are reserved for refugees, having separate entrance exams for refugees, and/or granting scholarships to refugees. The different schemes, with the oldest seeming to date back one decade, depend both on the nature of the university (if it is governmental, public but not governmental, or private) and on its internal decisions. The Universidade Católica de Santos, through its UNHCR Sergio Vieira de Mello Chair, published a study in October 2019 focusing on the documents needed for refugees to access universities, but which also provides information on some of these different schemes (Lapa et al. 2019). In some cases there are also initiatives that focus on supporting refugees once they are enrolled in the university, that is, focusing on entry, retention, and performance, with integration and follow-up actions, such as meetings with the coordinators of the courses that the students are enrolled in, meetings with the students themselves, guided tours, and providing access to financial support and to psychological and academic services.

\section{Research and Outreach}

Academia can play a significant role in public engagement activities, ranging from gathering and sharing evidence to inform policy and decision making in a technical manner, to developing efforts in relation to the surroundings and the environment in which the university is situated.

\section{Research, Policy, and Practice}

With reference to research, universities can assist in collecting and analyzing data to allow for both the development of fact-based scholarship and to share scientific knowledge. Besides publishing independent studies that could be used to support decision making, closer partnerships between universities and decision-making institutions could be relevant in this regard. An example of this in Brazil was the one-year research project "Migrantes, apátridas e refugiados: subsídios para o aperfeiçoamento de acesso a serviços, direitos e políticas públicas no Brasil" (Migrants, stateless persons, and refugees: subsidies for the improvement of access to services, rights, and public policies in Brazil) undertaken as part of the Ministry of Justice's Pensando o Direito (Thinking about the Law) program (Jubilut et al. 2015). This project resulted from a call for research to map the main obstacles faced by migrants, stateless persons, and refugees in accessing rights and services in the country in order to have empirical data to inform future public policies. The research produced a report of over one thousand pages, combining a national census on the topic with assessments of the main findings, and can be seen as an example of how universities can collaborate with decision-making bodies. Such an approach can have enormous impact, as universities can produce relevant, accurate, fact-based knowledge to aid the protection of refugees and other migrants.

Furthermore, universities can draw on scholarship and academic expertise to assess practices, policies, and norms, which is essential for all forms of protection, but is especially relevant 
in relation to refugees and other migrants in the current context, where one sees, on the one hand, limitations of rights, unwillingness to fulfill international obligations, and, in some cases, a lack of empathy and acts of racism and xenophobia, ${ }^{10}$ and, on the other hand, a process of norm-creation with the New York Declaration for Refugees and Migrants, ${ }^{11}$ the Global Compact on Refugees, ${ }^{12}$ and the Global Compact on Safe, Orderly and Regular Migration. This is due to the fact that, in a contrasting scenario such as this (characterized by widespread antimigrant sentiment while also trying to establish new bases for migration governance and migrants' protection), balanced, technical, and scientifically rigorous assessments are key to avoid decisions based only on opinions and to generate action based on facts, which seems particularly relevant in light of populist governments in Latin America.

Universities can also use these same standards to analyze specific initiatives and actions, to determine if they have protection at their core, are the best route for the achievement of the goal(s) they are set to reach, and/or if they can and actually do produce the desired results. Through academic knowledge, these assessments have a much better chance of being pertinent, accurate, and able to contribute positively to the protection of refugees and other migrants.

\section{Community Outreach}

In addition to engaging with policy makers and decision makers, a second strand of public engagement activities pertains to outreach that encompasses both actions directly benefiting refugees and other migrants, and the university's relation to the larger community (on such efforts in North American universities, see Abdo and Craven 2018; Moffette and Ridgley 2018; Vannini et al. 2018).

In Brazil, one can find initiatives on both fronts. Regarding benefits to refugees and other migrants, one could mention efforts that focus on teaching Portuguese to refugees and other migrants. In 2019, for instance, according to UNHCR Brazil, 18 of the above-mentioned UNHCR Sergio Vieira de Mello Chairs were engaged in this activity, with over 1,400 people in attendance. Such courses not only enhance integration experiences and outcomes but also promote access to rights and services. ${ }^{13}$ Moreover, law clinics and health services for refugees and asylum seekers have also been made available, as well as the possibility of revalidating university diplomas awarded abroad.

Regarding the wider community, universities can and do run essential activities that aim to raise awareness, share facts and data to enhance knowledge and understanding, and promote comprehension of and access to human rights, such as refugee and other migrants' protection rights. In this regard, universities can engage in initiatives ranging from convening events to organizing donation campaigns. Examples in Brazil include the annual public seminar of the UNHCR Sergio Vieira de Mello Chairs, specific events and lectures, a recent book donation campaign for indigenous children (from the Warao ethnic group) from Venezuela in the north of Brazil, ${ }^{14}$ donation campaigns for NGOs that directly support refugees and other migrants, ${ }^{15}$ and the creation of multicultural activities within events regarding music and gastronomy. ${ }^{16}$

These outreach initiatives by universities might, in turn, feed back into teaching and research components, besides directly and indirectly benefiting refugees and other migrants in different ways. In organizing such initiatives, it is essential for universities to remain aware of the risks of infringing on other actors' roles-such as creating a clash for resources with NGOs. The key here is that there should be collaboration and not competition, so that the most protective scenarios for refugees and other migrants can be created. 


\section{Academic Networks in Brazil and Latin America}

The possibility of sharing know-how and knowledge, developing research in partnerships and other forms of collaboration, and creating a regional grammar and vocabulary on refugee and other migrants' protection can benefit from strengthened regional and international networks.

A first initiative in this regard is the already mentioned UNHCR Sergio Vieira de Mello Chairs in Brazil, which, through its universities, can be said to have created an academic network on refugees in the country. Although the original idea was to also have these chairs in other Latin America countries (as the project stemmed from UNHCR Office for the Southern Part of South America, in Buenos Aires ${ }^{17}$ ), this initiative has not advanced beyond Brazil. Nonetheless, efforts to establish academic networks in the region and the participation of academics from the region in international initiatives have taken place.

The first of these to be mentioned, with multiple results, derives from the fact that the Refugee Law Reader ${ }^{18}$ has held an annual session in Latin America since 2014, which has led to the establishment of the Red Latino-Americana para el Derecho de Las Personas Refugiadas (Latin America Network for the Rights of Refugee Persons) under the initiative of the Hungarian Helsinki Committee in partnership with UNHCR Americas and the UNHCR Global Learning Center. The network has over 50 members, from professors of International Refugee Law to NGO and international organization staff; and focuses on tools for teaching International Refugee Law, exchanges on International Refugee Law in Latin America, cooperation in syllabus development, and updates on International Refugee Law topics and forced migration. ${ }^{19}$

A second initiative, originating from Brazil, is the email list of the Núcleo Interdisciplinar de Estudos Migratórios (Interdisciplinary Migration Studies Nucleus-NIEM) ${ }^{20}$ from Universidade Federal do Rio de Janeiro, which has been active since September 2000, counts over 1,800 members, and circulates emails daily, sharing information on current events, opportunities in academic events and publications, requests and consultations pertaining to migration issues, and other topics of interest in Migration and Refugee Studies.

Lastly, ${ }^{21}$ in terms of ongoing efforts, it is relevant to note the participation of Latin American scholars in international academic initiatives related to the Global Compacts: in relation to the Global Compact on Safe, Orderly and Regular Migration, in 2017 the International Organization for Migration created the Research Migration Leaders' Syndicate ${ }^{22}$ and invited three Latin American scholars to join it, ${ }^{23}$ and in relation to the Global Compact on Refugees, UNHCR is creating a Global Academic Network, which convened an initial workshop in November 2018 to which Latin American scholars were also invited. ${ }^{24}$

In terms of past networking efforts three should be mentioned. First, the fact that academics came together and debated and produced the "Declaration by Academia within the framework of Cartagena +30: Declaration on the Integral Protection of Refugees and Other Forced Migrants and for the Construction of an Effective Humanitarian Space"25 as a parallel document in the framework of the discussions of Cartagena $+30^{26}$ in 2014. Second, the Red Latinoamericana de Migración Forzada (The Latin American Network for Forced MigrationLANFM) which started in Colombia in 2010 and, albeit producing individual positive effects, has an "unfinished building process" (Sánchez-Mojica 2019). And third, albeit not successful due to lack of resources, in 2016 there was an initiative to establish a network on the protection of refugees in Latin America. The idea was to begin with a small "executive council" composed of scholars from different countries to think of ways to bring together academics who work with issues related to refuge and refugees in the region, in order to facilitate the exchange of good practices, experiences, data and information, inspiring collaborative works, actions and shared events, and if possible joint research projects. ${ }^{27}$ 


\section{Moving Forward}

Even with all these initiatives, cooperation in the construction of academic-focused networks and efforts in the region could be much stronger. This is relevant also in terms of knowledge sharing, as it might enhance information, assessment, and analysis exchanges both within the region and with actors from outside of the region, and aid in better situating research done by Latin American academics in the broader international field of Refugee and Forced Migration Studies. In the current scenario, there still seems to be a relevant gap and failure to include research by Latin Americans in the broader literature in this field. This could partly be explained by the fact that the main modes of publication are often Anglophone, but a lesser interest in regional topics should also be taken into consideration; when combined, these could lead to a marginalization of knowledge production arising from universities and scholars not positioned in the Global North (see also Mathews 2018). This gap is not as big as it was some years ago, but this seems to be more a result of individual efforts of Latin American scholars than from a recentering of the Global South in Refugee and Forced Migration Studies (on similar dynamics in Asia and the Middle East, respectively, see Mathews 2018 and Hanafi 2018).

A regional approach to universities' actions could also-besides being in keeping with the Global Compact on Refugees, which positively values regional cooperation and actions ${ }^{28}$-allow academics to call attention to local and regional scenarios, develop better assessments of local and regional contexts, and undertake analysis of and develop proposals for regional responses for the protection of refugees and other migrants. It could also assist in verifying how positive regional actions and best practices could be translated into the universal scenario.

It is also relevant to note that both regional and international collaborations should be conducted in a spirit of academic partnership, with local partners being able to equally contribute to initiatives, develop knowledge, and benefit from the resources (during and after the projects), so that a win-win scenario is created and the positive aspects of collaborations are really in place. In reality, this suggestion arises from the fact that there have been multiple complaints and criticisms, not only in Latin America, but across the Global South in general, of partnerships that seem anything but: with the feeling that Global North researchers have "used" Southern partners either as only fact gatherers, without respect for their knowledge of the local experiences and contexts but using their connections, and/or only as a formality to comply with a requirement from their funding schemes.

As a first step toward its modification, this situation requires increased opportunities for networking and knowledge sharing with, within, and across the Global South. In this regard, and in the context of Latin America, it is relevant to point out that Universidade Católica de Santos recently presented a successful bid to host the 2022 International Association for the Study of Forced Migration (IASFM) Conference. Hosting and convening an international event like this in Brazil will be an opportunity for both networking and knowledge sharing, and enhance the opportunities for the participation of Brazilian and Latin American scholars, due, for instance, to the proximity of the conference to their universities-which can reduce the resources needed to attend-as well as the possibility of presenting in Portuguese or Spanish and on topics from the region. It will also be an opportunity to further discuss the roles of the Global South and of diverse regions in relation to Refugee and Forced Migration Studies, as the theme of the conference is "Global Issues, Regional Approaches-Contexts, Challenges, Dialogues and Solutions."

Lastly, and in terms of looking to the future of how universities can be included in the protection of refugees and other migrants, it seems important to return to the relevance of the relationship between universities and decision-making entities-both national governments and international organizations-in the sense of highlighting the adequate representation and 
role that the former should have in forums with the latter. It is important that universities actually be heard and that their knowledge taken into consideration, ensuring that they are not just included as a "checklist item" to prove that governments and international organizations are "open" to contributions by other stakeholders. Universities should be active participants throughout all the phases of the decision-making process: before decisions are made, during the making of decisions, and afterward, in terms of both implementation and assessment.

In these ways, universities could effectively contribute to the enhancement of the protection of migrants, and a whole-of-society approach would actually be closer to being implemented.

LILIANA LYRA JUBILUT holds a PhD and a Master's degree in International Law from Universidade de São Paulo and an LLM in International Legal Studies from NYU School of Law. She is a Professor of the Postgraduate Program in Law at Universidade Católica de Santos. She was Visiting Scholar at Columbia Law School and Visiting Fellow at the Refugee Law Initiative. She was invited by IOM to be a Member of its Migration Research Leaders' Syndicate and is also an invited member of the Academic Council on the Global Compact for Migration. She has been working with refugee issues since 1999.

\section{NOTES}

1. See https://www.un.org/en/ga/search/view_doc.asp?symbol=A/RES/73/195.

2. The initiatives outlined herein are a selective and not an exhaustive list of past and ongoing academic initiatives in Latin America and Brazil focusing on refugees and other migrants.

3. The list of the chairs and more information on them can be found-in Portuguese-at https://www .acnur.org/portugues/catedra-sergio-vieira-de-mello/. A book on the activities of UNHCR Sergio Vieira de Mello Chairs in its first 15 years is being developed, to be published in 2020.

4. The previous editions occurred in 2007, 2011, and 2012. They took place in Rio de Janeiro (with Pontifícia Universidade Católica do Rio de Janeiro as the university partner), Brasília (Centro Universitário de Brasília and Faculdade de Direito do Sul de Minas), Curitiba (Universidade Federal do Paraná, Centro Universitário Autônomo do Brasil, and Faculdade de Direito do Sul de Minas), and Boa Vista (Universidade Federal de Roraima and Universidade Católica de Santos), respectively.

5. The course was created by Silvia M. O. S. Apolinário and the author, and has been taught by the author since its first edition. In the first two Silvia M. O. S. Apolinário also taught, and in the last one the author was joined by João Carlos Jarochinski Silva.

6. For instance, Universidade Federal do ABC and Universidade Federal da Integração Latino-Americana.

7. Including Universidade Federal do Paraná and Universidade Federal da Integração Latino-Americana.

8. As in the cases of Universidade Federal de Santa Maria and Universidade Federal da Integração Latino-Americana.

9. Among them, 14 also have UNHCR Sergio Vieira de Mello Chairs.

10. For more on the current international scenario in general, see https://www.weforum.org/agen da/2017/11/the-refugee-crisis-or-a-crisis-for-refugees/. And in Latin America, see, for instance, the current deals being celebrated by the US and Central American countries, the Venezuelan exodus and its consequences, and the return of Central American migrants from the US to their home countries via Mexico.

11. See https://www.un.org/en/ga/search/view_doc.asp?symbol=A/RES/71/1.

12. See https://www.unhcr.org/gcr/GCR_English.pdf.

13. Other institutions that are not universities often also offer Portuguese classes. Examples of this are the pioneering course in São Paulo offered by the Serviço Social do Comércio (SESC) and a range of initiatives led by the mayor of São Paulo. 
14. This campaign occurred in 2019 and was organized by Universidade Federal de Santa Catarina, with the support of Defensoria Pública da União, Universidade Católica de Santos, Universidade do Estado de Santa Catarina, and Universidade Federal de São Carlos.

15. For instance, Universidade Católica de Santos has held campaigns asking for food items and baby formula and diapers to benefit the Caritas Refuge Center in São Paulo and Missão Paz.

16. In terms of gastronomy, Universidade Católica de Santos has developed a special coffee break titled "Sabores e Refúgio" (Flavors and Refuge) in which examples of traditional foods from the biggest groups of refugees in Brazil are prepared by students and served.

17. This office encompassed Brazil at the time of the creation of the chairs. Since then, however, the UNHCR Brazil office has responded directly to UNHCR's headquarters.

18. See https://www.refugeelawreader.org/en/.

19. With thanks to Carolina Claro for the information on these topics.

20. NIEM is coordinated by Helion Povoa Neto, who is also the email list's moderator.

21. Other initiatives that have academic components could be mentioned. First, the American Network for Refugees' Legal Aid (known by its Spanish acronym, RALRA, https://www.ralra.org/en/), which was established in 2018 with the support of UNHCR and the Inter-American Institute of Human Rights. It has academics as members (alongside institutions), as well as a publication space (through blogs) and research initiatives. This initiative is not only for Latin America but rather for the whole continent. Second, a WhatsApp group called "Migración en las Américas" (Migration in the Americas), which self-defines as an "international network of organizations, activists and researchers," has over 255 members and exchanges information on current events, academic events and opportunities, and other migration-related topics. Third, the Migrantólogos network (http://www.migrantologos $. \mathrm{mx} / \mathrm{es} /$ ), active since 2009, gathers professors, researchers, scholars, and activists, based in Mexico but with a regional reach.

22. See https://www.iom.int/migration-research-leaders-syndicate.

23. Namely, Rodolfo Casillas R. (Mexico), Pablo Ceriani (Argentina), and Liliana L. Jubilut (Brazil).

24. For instance, Roberto Carlos Vidal (Colombia), Pablo Ceriani (Argentina), Laura Rubio Díaz Leal (Mexico), and Liliana L. Jubilut (Brazil).

25. See https://www.unisantos.br/wp-content/uploads/2014/11/Declaration-by-Academia-within-theframework-of-Cartagena.pdf.

26. The Cartagena Declaration is a document adopted in 1984 that is the basis for the creation of a regional refugee regime in Latin America. It has a review process with meetings every 10 years. In 2014 its 30th anniversary was celebrated, which led to the Cartagena +30 process and the adoption of the Brazil Declaration and Plan of Action.

27. As a disclaimer it is important to note that I conceived and coordinated the efforts both for the Declaration by Academia and the Network.

28. On the relevance of regionalism, see Jubilut and Ramos (2014).

\section{REFERENCES}

Abdo, Diva, and Krista Craven. 2018. "Every Campus A Refuge: A Small College’s Engagement with Refugee Resettlement." Migration and Society 1: 135-146.

Hanafi, Sari. 2018. "Postcolonialism's After-Life in the Arab World: Toward a Post-Authoritarian Approach." In The Handbook of South-South Relations, ed. Elena Fiddian-Qasmiyeh and Patricia Daley, 76-85. Oxford: Routledge.

Jubilut, Liliana L., and Erika Pires Ramos. 2014. "Regionalism as a Strategic Tool for Dealing with Crisis Migration." Forced Migration Review 45: 66-67.

Jubilut, Liliana L., et al. 2015. "Migrantes, apátridas e refugiados: subsídios para o aperfeiçoamento de acesso a serviços, direitos e políticas públicas no Brasil." [Migrants, stateless persons, and refugees: subsidies for the improvement of access to services, rights, and public policies in Brazil.] Brasília: 
Ministério da Justiça; IPEA. http://pensando.mj.gov.br/wp-content/uploads/2015/12/PoD_57_ Liliana_web3.pdf;_http://pensando.mj.gov.br/publicacoes/.

Lapa, Rosilandy, and Vanessa Vasques R. dos Reis, Ananda Pórpora Fernandes, Victor Augusto Mendes. 2019. Documentos para o acesso de pessoas refugiadas ao Ensino Superior no Brasil-Relatório de Pesquisa. [Documentation for the access by refugees to higher education in Brazil - Research Report] Santos: Cátedra Sérgio Vieira de Mello da Universidade Católica de Santos. https://www .unisantos.br/wp-content/uploads/2019/10/CSVM-UniSantos-Relato-de-Pesquisa-Documentospara-acesso-de-pessoas-refugiadas-ao-Ensino-Superior-no-Brasil-FINAL.pdf.

Mathews, Gordon. 2018. "South-South Relations in the Academic World: The Case of Anthropology." In Fiddian-Qasmiyeh and Daley, The Handbook of South-South Relations, 86-94.

Moffette, David, and Jennifer Ridgley. 2018. "Sanctuary City Organizing in Canada: From Hospitality to Solidarity." Migration and Society 1: 147-155.

Sánchez-Mojica, Beatriz Eugenia. 2019. "Bittersweet Symphony: Challenges and Lessons Learned from Network Building in Latin America." In McGrath and Young, Mobilizing Global Knowledge: Refugee Research in an Age of Displacement, 253-271.

Vannini, Sara, Ricardo Gomez, Megan Carney, and Katharyne Mitchell. 2018. "Interdisciplinary Approaches to Refugee and Migration Studies: Lessons from Collaborative Research on Sanctuary in the Changing Times of Trump." Migration and Society 1: 164-174. 